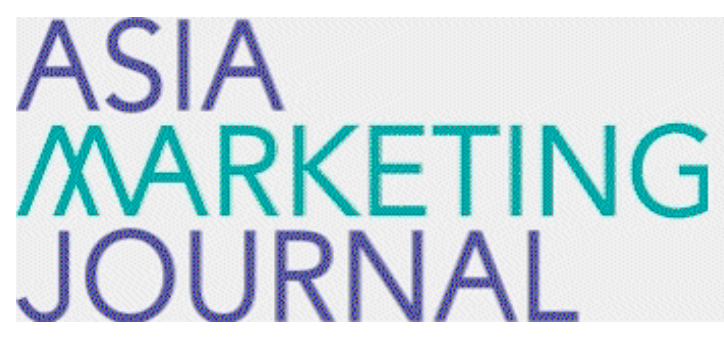

ASIA MARKETING JOURNAL

Volume 20 | Issue 3

Article 2

$10-31-2018$

\title{
The Impact of Salesperson Look-Brand Personality Congruence on Brand Affect
}

Heekyung Lee

Youjae Yi

Follow this and additional works at: https://amj.kma.re.kr/journal

Part of the Marketing Commons

\section{Recommended Citation}

Lee, Heekyung and Yi, Youjae (2018) "The Impact of Salesperson Look-Brand Personality Congruence on Brand Affect," Asia Marketing Journal: Vol. 20 : Iss. 3 , Article 2.

Available at: https://doi.org/10.15830/amj.2018.20.3.17

This Article is brought to you for free and open access by Asia Marketing Journal. It has been accepted for inclusion in Asia Marketing Journal by an authorized editor of Asia Marketing Journal. 


\title{
The Impact of Salesperson Look-Brand Personality Congruence on Brand Affect: The Moderating Role of Social Anxiety*
}

\author{
Heekyung Lee** \\ Youjae $\mathrm{Yi}^{* * *}$
}

Branded service encounters, in which various aspects of frontline employees are strategically aligned with the firm's brand positioning, can be achieved along several dimensions such as employee appearance, manner, and personality. While previous research has mainly focused on behavioral traits of employees, this research examines the employee's physical appearance in association with the brand personality trait across two studies. Study 1 shows that salesperson look-brand personality congruence enhances brand affect by inducing positive affect. Specifically, a brand-congruent look of a salesperson increases positive affect among customers by confirming their prior expectations about what a salesperson of a certain brand should look like as a brand representative. Study 2 reveals that the positive impact of salesperson look-brand personality congruence on brand affect is significant only for customers with high social anxiety whereas this effect disappears for those with low social anxiety. These findings extend previous research on branded service encounters by showing why and when frontline employees' physical appearance shapes customers' affective responses toward the brand.

Key words: Brand affect, Branded service encounters, Salesperson look, Brand personality, Social anxiety

This research was supported by the Institute of Management Research, Seoul National University.

** Doctoral Student, Seoul National University, College of Business Administration, Seoul, Korea (aragorn901@naver.com)

*** Professor of Marketing, Seoul National University, College of Business Administration, Seoul, Korea (youjae@snu.ac.kr), Corresponding Author 
Aesthetic labor (i.e., strategic control of the physical appearance of the salesperson to match the company's brand positioning) has been widely accepted by brand managers as an effective marketing tool in building and enhancing brand personality, which eventually serves as a competitive advantage that differentiates the brand from its competitors. For instance, a salesperson working for Clinique, a global cosmetic brand, wears a white lab coat that reminds customers of a medical doctor to emphasize the brand image as a skin doctor that tends to customers' skin problems. Furthermore, luxury brands such as Chanel and Hugo Boss strategically dress their salespeople in formal suits to promote the sophisticated brand image. Although the physical appearance of a salesperson has been playing such an important role in practice, only a little research empirically examined whether aesthetic labor actually creates emotionally gratifying consumption experience for customers, as expected by brand managers. Indeed, most prior studies that examined the relationship between the salesperson and brand perception have rather focused on the behavioral aspect of a frontline employee, demonstrating the impact of brand-associated behavior of the salesperson (Sirianni et al. 2013; Wentzel 2009).

Further, a few studies that did address the physical appearance of the salesperson have mainly discussed this issue in terms of human resource management, focusing on the impact of aesthetic labor on the employee's emotion and attitude (i.e., employee branding; Ind 2003; Mitchell 2002; Rafaeli et al. 1997). Despite the dyadic nature of consumption experience, the customer side of the story is neglected in aesthetic labor research.

For these reasons, this research attempts to examine the relationship between the overall physical appearance of frontline service providers and the strategic brand concept (Park, Jaworski and MacInnis 1986) in terms of its effect on customers' affective responses toward the brands. Specifically, across two studies, we show that strategically aligning the overall look of a salesperson with the brand personality (i.e., salesperson-brand congruence, hereafter) increases brand affect, which is defined as a brand's potential to elicit happy, joyful, or other emotional responses from the consumer as a result of its use (Chaudhuri and Holbrook 2001). We also explore the underlying mechanism behind the effect of salesperson-brand congruence on brand affect (i.e., salesperson-brand congruence effect) through the expectation-confirmation process, demonstrating the mediating role of positive affect. In addition, this research investigates the moderating effect of social anxiety, showing that the salesperson-brand congruence effect is stronger among customers with high social anxiety than among those with low social anxiety. 


\section{Theoretical Background}

\subsection{Impact of Salesperson-Brand Congruence on Brand affect}

As brand personality has been widely recognized as an effective marketing tool to achieve a competitive advantage, the importance of frontline employees is also emphasized more than ever as they play a crucial role in establishing and reinforcing the brand concept by directly interacting with customers (Barlow and Stewart 2004: Cialdini 1993; Pounders, Babin and Close 2015). Sirianni et al. (2013) have introduced the concept of "branded service encounters," in which frontline employees interact with customers through their brand-aligned behaviors. Although this research mainly focused on the behavioral traits of frontline employees, frontline employees can influence a customer's emotional association with the corporate brand not only by what they do and how they do it, but also by how they appear to the customer (Davies and Chun 2010). In fact, practitioners are widely adopting the concept of aesthetic labor in hopes of building the brand meaning and providing emotionally gratifying experience for customers (Pounders, Babin and Close 2015: Warhurst et al. 2000). For example, Abercrombie and Fitch (A\&F), an apparel retailer, is notorious for recruiting employees as much for their physical appearance as for their abilities. Indeed, A\&F not only selectively hires employees whose looks are congruent with the brand concept, but also applies the strict appearance policy to make sure frontline service providers maintain the typical A\&F look of "youthful, casual, and sensual American beauty" (Pounders, Babin and Close 2015). Ethnic restaurants (e.g., Indian and Chinese restaurants) also tend to recruit staff from the same culture as the restaurant theme and require their staff to wear the folk costume as uniform.

Previous studies on physical appearance of frontline service providers also suggest that salesperson-brand congruence would have a positive impact on brand affect. For instance, Davies and Chun (2010) revealed that customers evaluated the brand more favorably when a stereotypical belief driven by a salesperson's age (i.e., a visual cue that consists of a salesperson's physical appearance) is consistent with the brand personality trait. Specifically, customers were likely to evaluate the brand with the "competence" personality more favorably when a salesperson looked old (vs. young). This was because an expectation driven by an old salesperson (i.e., knowledgeable and professional) matched the brand personality trait of competence, whereas a stereotypical belief driven by a young salesperson (i.e., exciting and energetic) did not. Furthermore, Pounders, Babin and Close (2015) found that the brand-aligned appearance of a salesperson increases patronage intentions. Patronage intentions, by definition, are similar 
to brand loyalty, because the former represents "the likelihood of an ongoing relationship with the service provider in the form of future visits and purchase intentions" (Pounders, Babin and Close 2015, p. 673) and the latter is defined as the willingness of the consumer to repurchase the brand (Chaudhuri and Holbrook 2001). Indeed, Chaudhuri and Holbrook (2001) have shown that there is a positive relationship between brand loyalty and brand affect in that brands that make consumers "happy," "joyful," or "affectionate" prompt greater purchase loyalty. Taken together, these findings suggest that aesthetic labor increases brand affect.

Building on these findings, we propose that customers show more positive affect toward the brand when there is congruence (vs. incongruence) between the overall physical appearance of a frontline service provider and the brand personality trait.

\section{H1: Salesperson-brand congruence has a positive impact on brand affect.}

\subsection{The Mediating Role of Positive Affect and Expectation-Confirmation Model}

Brand personality serves as a competitive advantage that differentiates the brand from its competitors by creating unique consumption experience through associating symbolic meaning to goods and services (Aaker 1997; Fournier
1998; Keller 1993). In other words, brand personality bestows symbolic, personal meaning to the brand by attributing human characteristics to the brand, thereby ultimately strengthening the emotional bond between customers and the brand. Being well aware of this effect, marketers have invested significant time and effort in supporting the firm-selected brand image through strategic brand concept management (Park, Jaworski and MacInnis 1986), using five dimensions of brand personality: sophistication, ruggedness, sincerity, competence, and excitement (Aaker 1997). Because of such efforts, customers are constantly and repetitively exposed to advertisements and other promotional messages emphasizing the brand personality concept, and eventually develop certain impressions of a brand in a similar way they form an impression of a fellow human being. For example, when exposed to Harley-Davidson, customers naturally associate the brand with a person whose physical appearance matches the rugged personality trait of the brand, as intended by marketers. On the other hand, BMW tends to remind its customers of an image of a businessperson with refined taste whose overall appearance reflects the sophisticated personality of the brand.

Because frontline employees are commonly accepted as a reliable source of brand information and perceived as a brand representative (Huber and McCann 1982; Pounders, Babin and Close 2015), strategical positioning of brand personality not only influences customers' impressions of 
the brand itself but also creates stereotypical beliefs about what a typical salesperson for the brand should look like (Aggarwal 2004). That is, when exposed to brand positioning strategies that use brand personality, customers develop expectations that a salesperson, as a brand representative, should have a physical appearance that reflects the personality of the brand. Previous studies on stereotyping suggest that when such expectations are confirmed by the brand-congruent appearance of the salesperson (i.e., stereotype-consistent information), customers would feel positive affect, whereas brandincongruent look (i.e., stereotype-inconsistent information) would lead to negative affect (Costrich et al. 1975; Jackson and Cash 1985). This positive (negative) affect driven by the confirmation (violation) of stereotype-based expectancies about the frontline employee would extend to that toward the brand when customers perceive him (her) as an exemplar of the brand (Crawford, Sherman and Hamilton 2002). However, when the frontline employee is considered more strongly as an individual with a unique set of characteristics, the individual salesperson is disassociated from his (her) group membership of a brand ambassador (i.e., subtyping; Kunda and Oleson 1995), and an impression one makes of that salesperson is not transferred to a general impression of the brand.

Building on these findings, we propose that when there is salesperson-brand congruence, customers feel greater positive affect from stereotype-consistent information processing, and this increase in positive affect eventually leads to greater brand affect. When encountered with a salesperson whose overall look matches the personality of the brand, customers feel positive affect because the actual look of a salesperson is consistent with their prior expectations about the salesperson as a brand representative (i.e., expectation-confirmation process). This increase in positive affect driven by salespersonbrand congruence extends to that toward the brand, increasing brand affect eventually.

H2: Positive affect mediates the relationship between salesperson-brand congruence and brand affect. Salesperson-brand congruence increases positive affect, which in turn increases brand affect.

\subsection{The Moderating Effect of Social Anxiety}

Although testing the main effect of salesperson - brand congruence is an important contribution on its own, we expect that the effect will vary depending on customers' personality traits. We thus explore the potential moderating effect of a dispositional social anxiety, a negative social emotion that has a great potential to influence customers' interactions with salespeople. Social anxiety is defined as anxiety resulting from the prospect or presence of personal evaluation in real or imagined social situations such as 
conversations with strangers and customersalesperson interactions (Bagozzi and Dholakia 2006; Cacioppo, Glass and Merluzzi 1979; Schlenker and Leary 1982). As a negative social emotion, social anxiety can influence customers' reactions to service encounters with frontline employees by activating customers' self-presentation concerns as a result of impression management efforts (Fenigstein, Scheier and Buss 1975). In other words, social anxiety, being significantly correlated with public consciousness and self-presentation concerns, can motivate customers to avoid interacting with a salesperson out of fear that they may not be able to make a good impression of themselves. In fact, socially anxious individuals are hesitant about talking to strangers, avoid extensive interpersonal interactions in uncertain environments, and eventually feel more satisfaction from consumption experience when there is less social contact with salespeople (Bearden, Malhotra and Uscategui 1988; Fenigstein, Scheier and Buss 1975). Also, people with high social anxiety are generally more apprehensive about interacting with an attractive other (Wenzel and Emerson 2009) out of concern that (s) he may make an unfavorable evaluation of them (Wan and Wyer 2015). Social anxiety fluctuates over time and across situations, but there are individual differences (produced by personal experience and probably biological factors) in the degree to which people experience it (Schlenker and Leary 1982). The present research will focus on chronic social anxiety as a dispositional trait that influences customers' reaction to daily service encounters.

Findings from previous studies suggest that when a salesperson has brand-congruent look, customers perceive him (her) as a source of brand information rather than as a target of their impression-management efforts, and customers' encounter with the salesperson becomes less personal. As a result, customers with high social anxiety would feel less obliged to make good impressions of themselves to the salesperson

〈Figure 1〉 Conceptual Model

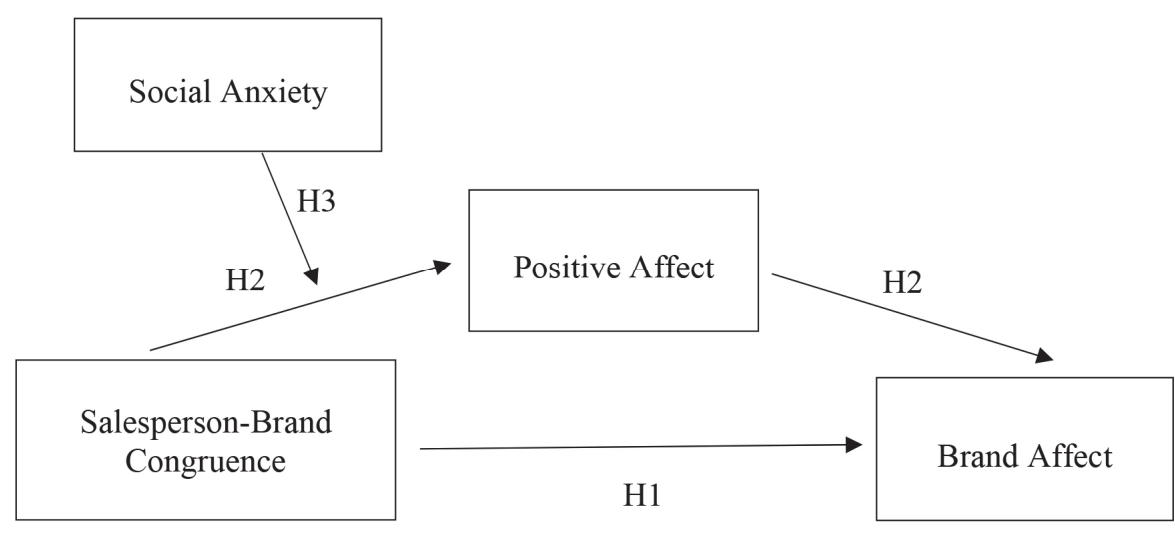


with brand-congruent look than to the one with brand-incongruent look, thus feeling less social discomfort. On the other hand, the positive impact of salesperson-brand congruence on positive affect may be relatively weaker for customers with low social anxiety in a sense that they get less nervous about strangers in the first place, and accordingly are less likely to notice the differences in the salesperson's appearance.

In sum, we propose that salesperson-brand congruence results in greater positive affect (i.e., less emotional discomfort) among customers with high social anxiety than those with low social anxiety. This increased positive affect will in turn lead to greater affective response toward the brand.

H3: Social anxiety moderates the effect of salesperson-brand congruence on brand affect via positive affect. The effect of salesperson-brand congruence on positive affect is stronger for customers with high social anxiety than for those with low social anxiety. This increased positive affect in turn leads to greater brand affect.

\section{Study 1}

Study 1 tests whether salesperson-brand congruence influences brand affect (H1) and whether positive affect mediates this relationship between congruence and brand affect (H2). Measures and the manipulation method used in this experiment are adopted from Sirianni et al. (2013) that examined whether brand personality-employee behavior alignment elicits positive affective responses toward the brand.

\subsection{Method}

\subsubsection{Subjects}

A sample of 275 individuals (age ranging from 20 to 77) was recruited from Amazon Mechanical Turk (MTurk, hereafter) to participate in the experiment in exchange for $\$ 1$. All participants were female to control for the possible effect of gender congruence between salesperson and customer (i.e., same sex, opposite sex) on brand affect. IMC (Instructional Manipulation Check) questions were adopted to screen out participants who have difficulty understanding English and those who are not paying attention during the experiment (Goodman, Cryder and Cheema 2013; Oppenheimer, Meyvis and Davidenko 2009). Out of 275 participants, two of them did not answer the IMC questions correctly and data from these two participants were eliminated.

\subsubsection{Design \& procedures}

The experiment employed a 2 (brand personality 
: rugged vs. sophisticated ${ }^{1)}$ ) x 2 (overall salesperson look: rugged vs. sophisticated) between-subjects design. Participants read one of the four randomly assigned scenarios and answered the questions. All four scenarios, adopted and modified from the scenario excerpt from Sirianni et al. (2013), were divided into two parts. Participants were first shown the scenario that describes the personality of the imaginary brand (i.e., $\mathrm{R}$ or $\mathrm{S}$, respectively rugged or sophisticated brand), which is assumed to be the leading apparel company in U.S. The scenario described the personality of rugged brand as outdoorsy, rugged, sturdy, rock-solid, hardy, strong, and durable (Aaker 1997). In the sophisticated brand personality condition, participants read the scenario accentuating upscale, glamorous, sophisticated, fashionable, smooth, charming, and refined traits (Aaker 1997).

After finishing this first part of the scenario, participants were able to move to the next part of the scenario describing the situation that a female participant (customer) visits the $\mathrm{R}$ or $\mathrm{S}$ brand dealership and encounters a male (opposite sex) salesperson. In the brand-congruent condition, participants read "Imagine yourself in an R/S brand dealership. As you walk in, the salesperson A greets you. His overall style is a typical brand-R/S-look that you have expected to see." In the brand-incongruent condition, participants read "Imagine yourself in an R/S brand dealership. As you walk in, the salesperson A greets you. His overall style is far from a typical brand-R/S-look that you have expected to see." Specifically, the rugged salesperson look was described as "masculine and wild overall, tanned, looks physically strong and healthy, wearing casual, outdoorsy outfits such as a T-shirt and jeans," whereas the sophisticated salesperson look was described as "looking polished, cultured and sophisticated overall: he is in a suit, has a fair skin, and his hair is well-groomed and refined-looking."

\subsubsection{Measures}

After reading the scenario, participants answered the questions measuring dependent variables. Brand affect was measured as an average of three 7-point items (Chaudhuri and Holbrook 2001). Participants reported the level of agreement with each of the following three statements: "I feel good when I use this brand," "This brand makes me happy" and "This brand gives me pleasure" $(1=$ completely disagree, $7=$ completely agree). Reliability analysis showed

1) Among five dimensions of brand personality, for more reliable and successful manipulations, we chose ruggedness and sophistication, which were already empirically tested and successfully manipulated in Sirianni et al (2013). Furthermore, we found these particular dimensions appropriate for this research because they were relatively more easily and objectively translated into a salesperson's physical appearance, compared with other three dimensions (i.e., sincerity, competence, and excitement). 
the scale was unidimensional and Cronbach's alpha was .95. Positive affect was measured as an average of four 7-point items (Allen and Janiszewski 1989) : bad/good, negative/positive, unpleasant/pleasant, and sad/happy. These four items turned out to be highly reliable to measure positive affect (Cronbach's alpha $=.96$ ).

After completing the dependent measures, participants answered manipulation check questions. Their perceptions of (1) the salesperson's rugged and sophisticated look traits and (2) the brand's rugged and sophisticated personality traits were measured with six 11-point items (i.e., 1 = not at all, 11 = very much), which asked participants to rate the extent they think each of the six adjectives (i.e., rugged, tough, resilient, sophisticated, refined, cultured) describes (1) the characteristics of the salesperson's look or (2) R/S brand's personality (Aaker 1997; Weber and Crocker 1983). We created the rugged salesperson look index by averaging the three items that measured rugged characteristics of a salesperson look (i.e., athletic, tough, and resilient; $\alpha=$.94) and the sophisticated salesperson look index by averaging the other three items that measured sophisticated characteristics of a salesperson look (i.e., sophisticated, refined, and cultured; $\alpha=.97)$. Furthermore, rugged brand personality was measured as an average of three items (i.e., rugged, tough, resilient; $\alpha=.98)$ and sophisticated brand personality was measured as an average of other three items (i.e., sophisticated, refined, and cultured; $\alpha=.97)$.

\subsection{Results}

\subsubsection{Manipulation checks}

We tested the manipulations of salesperson look trait and brand personality with a series of one-way ANOVAs. First, a one-way ANOVA with rugged characteristics of salesperson look as the dependent variable revealed a significant main effect of salesperson look characteristic $(F(1,271)=550.63, p<.001)$. As expected, the salesperson was perceived as more rugged looking in the rugged look condition $\left(M_{\text {rugged }}=\right.$ 5.83) than in the sophisticated look condition $\left(M_{\text {sophisticated }}=2.39\right.$ [out of 7$\left.]\right)$. Second, a oneway ANOVA with sophisticated characteristics of salesperson look as the dependent variable showed a significant main effect of salesperson look characteristic $(\mathrm{F}(1,271)=534.01, p<.001)$. As expected, participants in the sophisticated look condition perceived the salesperson as more sophisticated looking than those in the rugged look condition $\left(M_{\text {sophisticated }}=6.09\right.$ vs. $M_{\text {rugged }}=$ 2.66 [out of 7]). Third, a one-way ANOVA of brand personality trait (rugged vs. sophisticated) on the rugged brand personality index showed a significant main effect $\left(M_{\text {sophisticated }}=2.35\right.$ vs. $M_{\text {rugged }}=6.10 ; \mathrm{F}(1,271)=959.75, p<$ .001). Fourth, a one-way ANOVA with the sophisticated brand personality index as the dependent variable revealed a significant main 
effect of brand personality trait $\left(M_{\text {sophisticated }}=\right.$ 6.25 vs. $M_{\text {rugged }}=2.43 ; \mathrm{F}(1,271)=996.78$, $p<.001)$.

\subsubsection{The effect of salesperson-brand congruence on brand affect}

To test hypotheses that examine the impact of salesperson-brand congruence on brand affect, the "congruence" variable was created: the "rugged salesperson-rugged brand" condition and the "sophisticated salesperson-sophisticated brand" condition were classified as "congruence," whereas the "rugged salesperson-sophisticated brand" condition and the "sophisticated salesperson -rugged brand" condition were labeled as "incongruence." In the following analyses, the "congruence" variable was coded such that the salesperson-brand congruent condition $=1$ and the incongruent condition $=0$.

We first conducted a 2 (salesperson-brand congruence: congruent vs. incongruent) x 2 (brand personality: rugged vs. sophisticated) ANOVA to check whether the effect of salesperson-brand congruence varies according to brand personality. The results revealed a significant main effect of congruence $(\mathrm{F}(1,269)$ $=5.55, p<.05)$. Neither the main effect of brand personality $(\mathrm{F}(1,269)=1.28, p>.05)$ nor the interaction effect of congruence $\mathrm{x}$ brand personality $(\mathrm{F}(1,269)=.76, p>.05)$ was significant. As the results did not vary according to brand personality (rugged or sophisticated), the data were pooled across two types of brand personality in subsequent analyses.

Next, we conducted a one-way ANOVA to test the effect of salesperson-brand congruence on brand affect. The results showed that participants in the congruent condition reported greater brand affect than those in the incongruent condition $(\mathrm{F}(1,271)=5.38, p<.05)$, supporting H1. That is, participants felt greater brand affect when the overall look of a salesperson was congruent with the (rugged or sophisticated) brand personality $\left(M_{\text {congruent }}=5.62\right)$ than when it was incongruent $\left(M_{\text {incongruent }}=5.30\right.$ [out of 7 ]).

\subsubsection{The mediating role of positive affect}

To test whether positive affect mediates the impact of salesperson-brand congruence on brand affect (H2), a bootstrapping analysis was conducted using PROCESS Model 4 (Hayes 2013). Using 5,000 bootstrapping samples, the procedure showed a significant indirect effect of salesperson-brand congruence on brand affect via positive affect $(\beta=.25,95 \% \mathrm{CI}=$ $[.11, .41]$; incongruent $=0$, congruent $=1$ ). On the other hand, the direct path turned out to be insignificant $(\beta=.06, \mathrm{t}(271)=.51$, $p=.60$ ), suggesting that positive affect fully mediated the relationship between salesperson -brand congruence and brand affect. Specifically, salesperson-brand congruence led to greater positive affect $(\beta=.47, \mathrm{t}(271)=3.46, p<$ .001 ), which in turn increased brand affect in 
the end $(\beta=.54, \mathrm{t}(271)=10.81, p<.0001$; see figure 2), supporting $\mathrm{H} 2$.

\subsection{Discussion}

Results of Study 1 show that aligning brand personality and salesperson look increases brand affect (i.e., salesperson-brand congruence effect) and that positive affect is the underlying mechanism behind the relationship between salesperson-brand congruence and brand affect, supporting $\mathrm{H} 1$ and $\mathrm{H} 2$. These results suggest that brand-congruent look of a salesperson increases brand affect via positive affect, confirming customers' prior expectations that a salesperson of the certain brand should have a look that reflects social identity of a brand representative.

One may point out that our findings lack generalizability, given the fact that Study 1 was conducted only among female participants and did not consider the customer-salesperson gender congruence variable. To overcome this limitation, Study 2 is conducted among male participants, and gender congruence between customer and salesperson is also added as a control variable. That is, Study 2 extends the experimental setting by including the same sex situation in addition to the opposite sex setting. Study 2 also seeks the boundary condition of the salesperson-brand congruence effect by examining the moderating effect of social anxiety.

\section{Study 2}

In addition to testing the effect of salesperson -brand congruence on brand affect (H1) and the mediating effect of positive affect (H2) in a different context, Study 2 examined the moderating role of social anxiety in the relationship between salesperson-brand congruence and brand affect (H3). Study 2 incorporated the

〈Figure 2〉 The Mediating Role of Positive Affect (Study 1, H2)

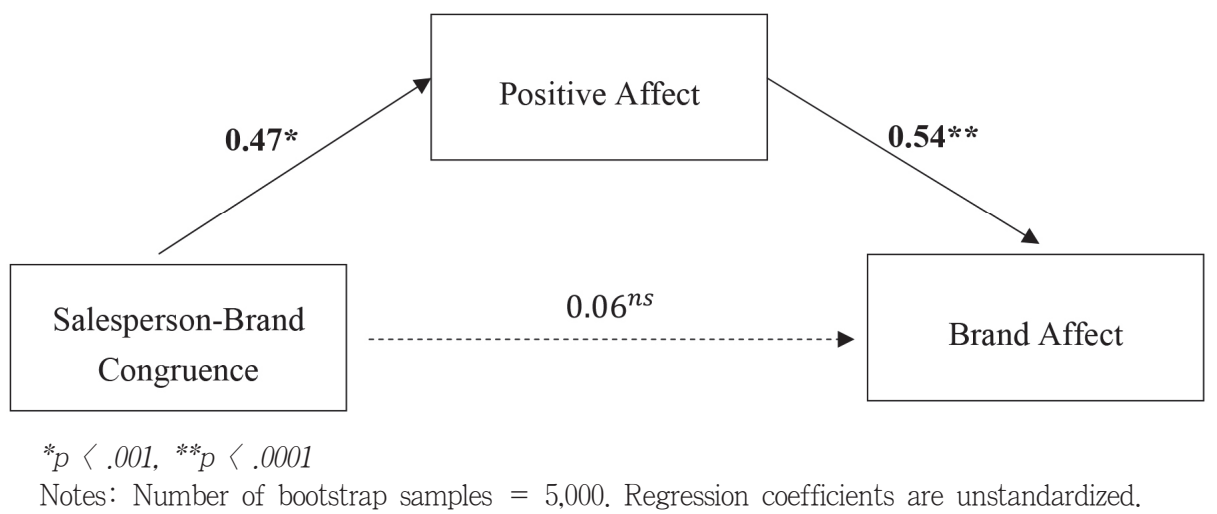

The Impact of Salesperson Look-Brand Personality Congruence on Brand Affect: The Moderating Role of Social Anxiety 27 
same experimental procedures used in Study 1 with a few modifications. While Study 1 focused on the opposite sex condition, Study 2 controlled for and examined the possible effect of the "salesperson-customer gender congruence" variable by adding it to the experiment design. Social anxiety as a dispositional variable was measured along with other dependent variables such as brand affect and positive affect.

\subsection{Method}

\subsubsection{Subjects}

A sample of 178 male participants between the age of 19 and 70 years $(\mathrm{M}=36.16, \mathrm{SD}=$ 10.03) were recruited from MTurk to participate in the experiment in exchange for \$1.5. Unlike Study 1, in which all of the participants were female, we conducted Study 2 among male participants for the diversity of the sample.

\subsubsection{Design \& procedures}

The experiment employed a 2 x 2 betweensubjects design with gender congruence as a covariate, in which salesperson look (rugged vs. sophisticated), brand personality (rugged vs. sophisticated) and gender congruence (same sex vs. opposite sex) were manipulated. Brand personality was manipulated with the same scenarios used in Study 1, except for that the certain expressions that may hint the size and reputation of the imaginary brand (i.e., R/S brand is one of the nation's leading $\cdots$ companies with many stores located across the United States) were changed to neutral expressions (i.e., R/S brand is the $\cdots$ retailer with its store located across the United States) in order to eliminate the possible bias. In order to control for the "salesperson-customer gender congruence" variable, the second part of the scenario described the appearance of a female (i.e., opposite sex) or male (i.e., same sex) salesperson whose look is characterized as either rugged or sophisticated. For example, a rugged female salesperson look was described as follows: "She looks outdoorsy and tough, overall. She is tanned and looks physically fit, strong and healthy. She has a natural hairstyle, with her hair let down and loose. She is wearing casual, outdoorsy outfits such as a leather jacket, T-shirt, jeans and western boots." A sophisticated female salesperson look was described as follows: "She looks polished and sophisticated overall. She has a formal, office look, wearing a tailored jacket and an h-line, midi skirt. She has a fair skin, and her hair is neatly done and refined looking." Gender congruence was manipulated by using either a female (opposite sex) or a male (same sex) salesperson.

Prior to the manipulation of salesperson look and brand personality, dispositional social anxiety was measured using eleven 7-point items (e.g., "I often feel nervous even in casual get-togethers"; $\alpha=0.95)$ developed by Leary 
(1989). Participants answered the social anxiety scale before they were exposed to the stimulus, thus guarding against potential contaminations (Rao and Monroe 1988).

\subsubsection{Measures}

After reading the scenario, participants answered the questions measuring dependent variables. We used the same scales as in Study 1 to measure brand affect ( $\alpha=.96$ ) and positive affect ( $\alpha=.95$ ). After completing the dependent measures, participants answered manipulation check questions. Their perceptions of the brand personality were measured with ten 7-point items (i.e., $1=$ not at all, 7 = very much) adopted from Aaker (1997), which asked participants to rate the extent to which they think each item describes the brand's rugged or sophisticated personality. Also, participants' perceptions of the salesperson's look traits were measured with eight 7-point items ${ }^{2)}$ (i.e., $1=$ not at all, $7=$ very much) adopted from Aaker (1997), which asked participants to rate the salesperson look from the scenario.

We created the rugged salesperson look index by averaging the four items that measured rugged characteristics of a salesperson look (i.e., outdoorsy, athletic, tough, country-western; $\alpha=.96)$ and the sophisticated salesperson look index by averaging the other four items that measured sophisticated characteristics of a salesperson look (polished, sophisticated, glamorous, upper-class; $\alpha=.97$ ). Furthermore, rugged brand personality was measured as an average of five items (i.e., rugged, tough, strong, country-western, outdoorsy; $\alpha=.98$ ), whereas sophisticated brand personality was measured as an average of the other five items (i.e., sophisticated, glamorous, smooth, upperclass, charming; $\alpha=.97$ ).

\subsection{Results}

\subsubsection{Manipulation checks}

The manipulations of salesperson look and brand personality were successful. First, a MANOVA with salesperson ruggedness $(\mathrm{F}(1,176)=368$. $68, p<.001)$ and sophistication $(\mathrm{F}(1,176)=$ 235.25, $p<.001)$ as dependent variables showed a significant main effect of salesperson look characteristics. That is, participants in the rugged look condition rated the salesperson look as more rugged than those in the sophisticated look condition $\left(M_{\text {rugged }}=5.25\right.$ vs. $M_{\text {sophisticated }}$ $=3.04$ [out of 7]), and participants in the sophisticated look condition rated the salesperson as more sophisticated looking than those in the rugged look condition $\left(M_{\text {sophisticated }}=5.48\right.$ vs.

2) Among the ten items used to describe brand personality traits, some expressions (i.e., rugged, strong, smooth, charming) that were not appropriate for describing a salesperson's look were replaced with more generally used expressions (i.e., athletic, polished). 
$M_{\text {rugged }}=2.90$ [out of 7]. Second, a MANOVA with brand ruggedness $(F(1,176)=316.76$, $p<.001 ; M_{\text {rugged }}=5.43$ vs. $M_{\text {sophisticated }}=2.95$ [out of 7$])$ and brand sophistication $(F(1,176)$ $=462.53, p<.001 ; M_{\text {sophisticated }}=6.19$ vs. $M_{\text {rugged }}=2.40$ [out of 7]) as dependent variables showed a significant main effect of brand personality trait.

\subsubsection{The effect of salesperson-brand congruence on brand affect}

As in Study 1, the "congruence" variable was created to test hypotheses that examine the impact of salesperson-brand congruence on brand affect (congruent $=1$, incongruent $=0$ ) . Additionally, the "gender congruence" variable was created such that male participants assigned to the female salesperson scenario were categorized as "opposite sex (coded as 1)," whereas those assigned to the male salesperson condition were labeled as "same sex (coded as 0)."

$2 \times 2$ ANOVA with a covariate of gender congruence showed a significant main effect of salesperson-brand congruence on brand affect $\left(\mathrm{F}(1,173)=8.06, p<.01 ; M_{\text {congruent }}=4.86\right.$ vs. $M_{\text {incongruent }}=4.26$ ), in support of H1. The main effect of brand personality was also significant $\left(F(1,173)=4.509, p<.05 ; M_{\text {rugged }}\right.$ $=4.34$ vs. $\left.M_{\text {sophisticated }}=4.79\right)$. The interaction of brand personality $\mathrm{x}$ salesperson-brand congruence $(\mathrm{F}(1,173)=.03, p>.05)$ or the covariate of gender congruence $(\mathrm{F}(1,173)=$
.46, $p>.05)$ did not have a significant effect on brand affect. As the results varied according to brand personality (rugged vs. sophisticated), we included brand personality as a covariate in subsequent analyses.

\subsubsection{The mediating role of positive affect}

To establish whether positive affect mediates the impact of salesperson-brand congruence on brand affect (H2), a bootstrapping analysis was conducted using PROCESS Model 4 (Hayes 2013) with gender congruence and brand personality variables controlled for. Using 5,000 bootstrapping samples, the results showed a significant indirect path of "salesperson-brand congruence $\rightarrow$ positive affect $\rightarrow$ brand affect" $(\beta=.38,95 \% \mathrm{CI}=$ $[.15, .65]$; incongruent $=0$, congruent $=1$ ), supporting H2. On the other hand, the direct path turned out to be insignificant $(\beta=.22$, $\mathrm{t}(173)=1.20, p=.23$ ), suggesting that positive affect fully mediated the relationship between salesperson-brand congruence and brand affect. Specifically, brand-congruent salesperson look increased positive affect among participants $(\beta=.59, \mathrm{t}(173)=3.27, p<.01)$ and this positive affect in turn significantly increased brand affect $(\beta=.65, \mathrm{t}(173)=8.75, p<.001$; see figure 3$)$. 


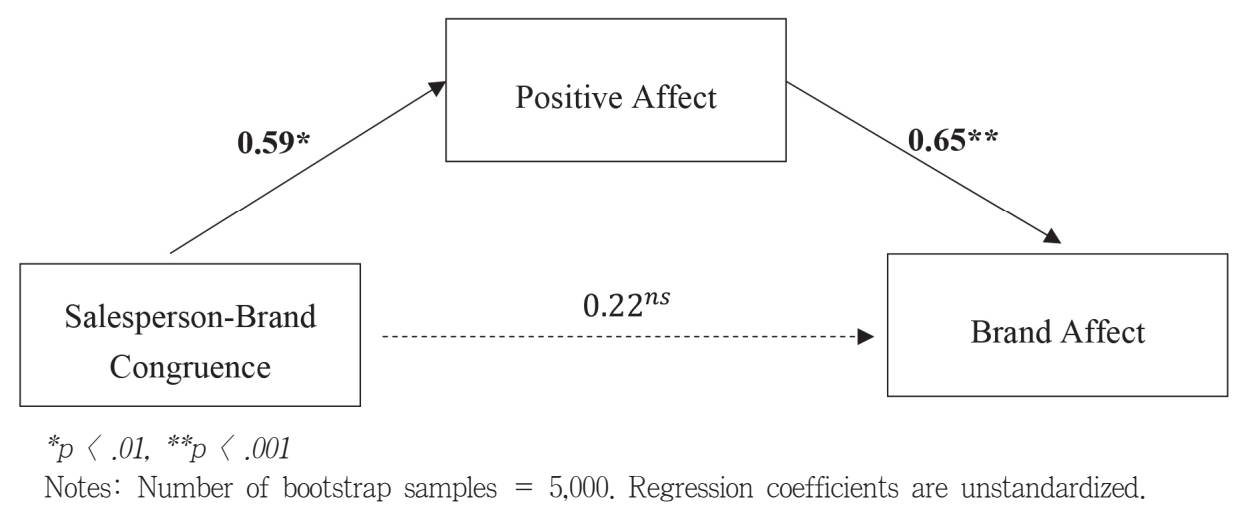

\subsubsection{The moderating effect of social anxiety}

Next, a mediated moderation analysis was conducted to test whether social anxiety moderated the effect of positive affect in the relationship between salesperson-brand congruence and brand affect (H3). Specifically, we performed a mediated moderation analysis using PROCESS Model 8 (Hayes 2013; 5,000 resamples), with brand affect as a dependent variable, salesperson -brand congruence as an independent variable, positive affect as a mediator, social anxiety as a moderator with covariates of gender congruence and brand personality. The results showed a significant interaction effect of salesperson -brand congruence $\mathrm{x}$ social anxiety on brand affect via positive affect ( $\beta=.15,95 \% \mathrm{CI}=$ $[.005, .31])$, consistent with H3. That is, salesperson-brand congruence and social anxiety had a significant interaction effect on positive affect $(\beta=.23, \mathrm{t}(173)=2.06, p<.05)$, which in turn significantly increased brand affect ( $\beta=$ $.68, t(173)=8.84, p<.001$; see figure 4$)$.

To look more deeply into this pattern of results, a separate spotlight analysis was conducted to examine the effect of salesperson -brand congruence on positive affect among participants who were high and low in chronic social anxiety (i.e., 1 standard deviation above and below the mean value; Krishna 2016; Spiller et al. 2013). Specifically, we conducted a spotlight analysis using PROCESS Model 1 with covariates of gender congruence and brand personality to test the moderating effect of social anxiety on the relationship between salesperson-brand congruence and positive affect when gender congruence is controlled for. Using 5,000 bootstrapping samples, the procedure indicated a significant interaction effect of salesperson-brand congruence $\mathrm{x}$ social anxiety on positive affect $(\beta=.23, \mathrm{t}(173)=2.06$, $p<.05)$. That is, when social anxiety is high (i.e., social anxiety $=5.75$ ), salesperson-brand 
〈Figure 4〉 Mediated Moderation Analysis (Study 2, H3)

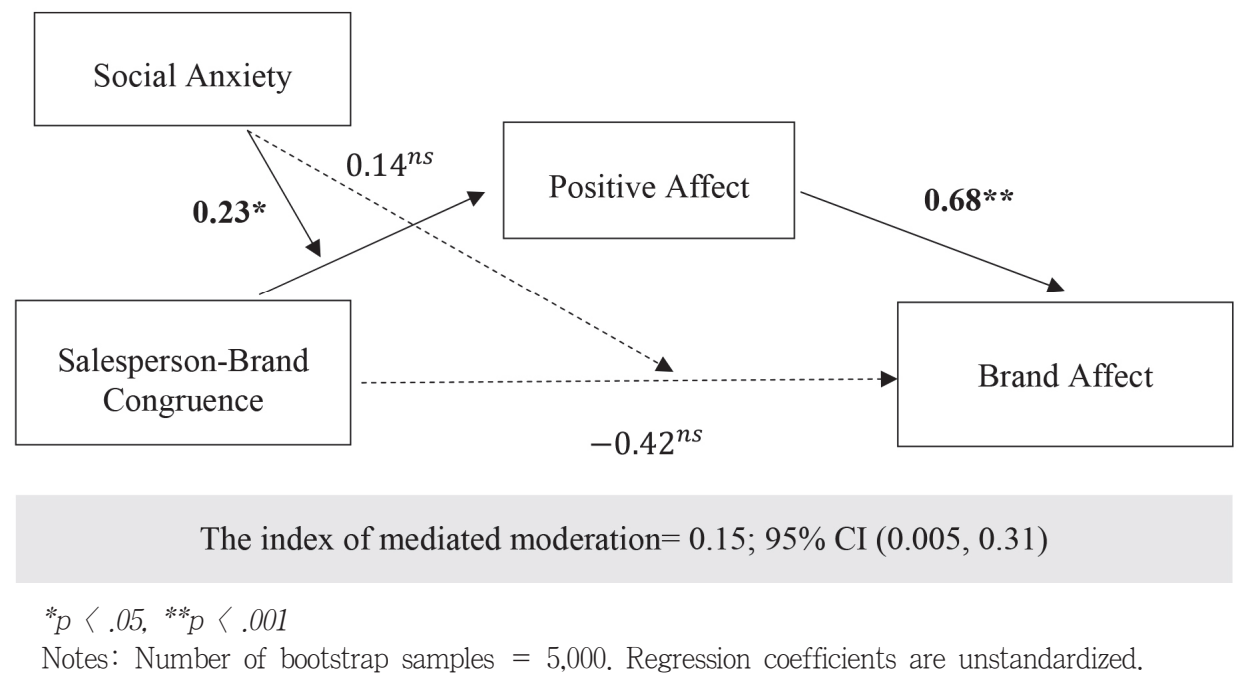

Notes: Number of bootstrap samples $=5,000$. Regression coefficients are unstandardized.

congruence significantly increases positive affect $(\beta=1.02$, t $(173)=4.16, p<.001$; incongruent $=0$, congruent $=1)$. However, when social anxiety is low (i.e., social anxiety $=2.55$ ), the impact of salesperson-brand congruence on positive affect is not significant ( $\beta=.30, \mathrm{t}(173$ ) $=1.18, p=.24$; see Figure 5), supporting H3.

\subsection{Discussion}

Study 2 not only replicates the findings from Study 1 but also shows the moderating effect of social anxiety on the relationship between salesperson-brand congruence and brand affect, testing H1-H3 among male participants with gender congruence controlled for. Specifically, Study 2 provides further evidence that salesperson -brand congruence increases brand affect and that positive affect mediates this relationship.
Furthermore, Study 2 sheds more light on the boundary condition of social anxiety. Salesperson -brand congruence significantly increases positive affect only when a customer has a high level of social anxiety, whereas salesperson-brand congruence has no significant effect on positive affect when a customer has a low level of social anxiety. More specifically, mediated moderation analysis results demonstrate that positive affect mediates the interaction effect of salesperson -brand congruence and social anxiety on brand affect. That is, customers with high social anxiety feel more positive affect when salesperson look is congruent with brand personality, possibly because they find the salesperson as the representative of the brand rather than as an individual on whom they should present good impressions of themselves. On the other hand, for customers with low social anxiety who do 
〈Figure 5〉 The Moderating Effect of Social Anxiety on Relationship between Salesperson-Brand Congruence and Positive Affect (Study 2, H3)

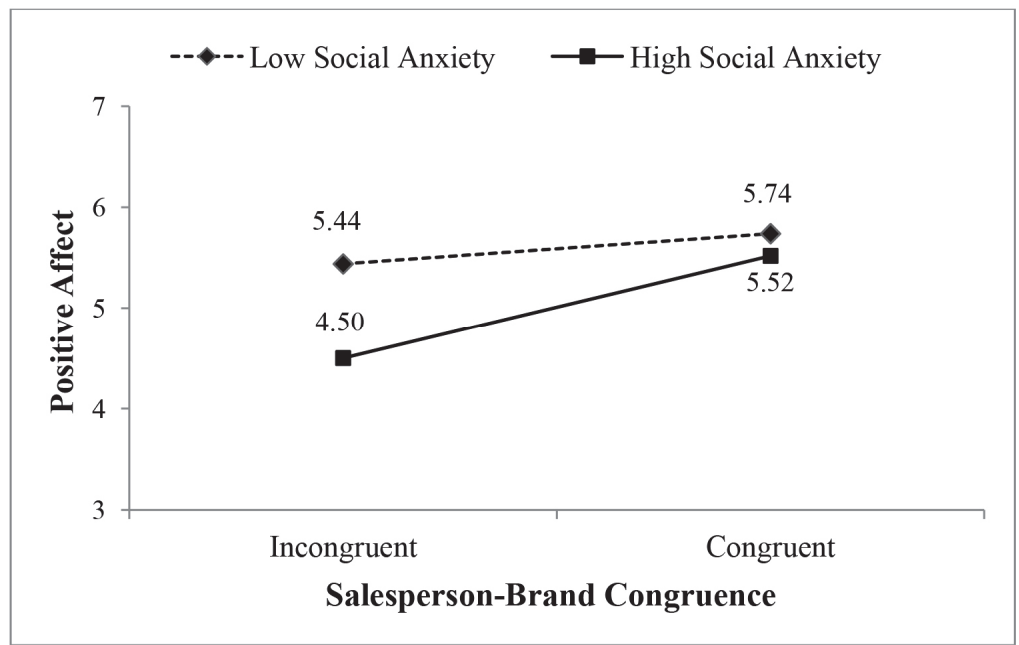

not usually feel nervous around the salesperson in the first place, salesperson-brand congruence does not have a significant impact on brand affect.

\section{General Discussion}

As brand personality has been emphasized as a competitive advantage that differentiates brands from each other by associating symbolic meaning to the brands, frontline employees are increasingly recognized as an effective tool to construct and deliver brand personality to customers because they are an important source of brand information who interact directly with customers. Despite the growing interest in frontline employees' role as the brand ambassador and the widespread utilization of aesthetic labor in the service retail industry, relatively little research has addressed this issue empirically. Indeed, most prior studies on branded service encounters have rather focused on the behavioral aspect of a salesperson, and a few studies on aesthetic labor have been mainly concerned with its impact on employees' emotion and behavior rather than those of customers. Our research contributes to the existing literature by filling this gap, empirically examining the relationship between frontline employees' physical appearance and brand positioning strategy.

\subsection{Theoretical Implications}

Across two studies, our research not only reveals a significant effect of salesperson-brand 
congruence on brand affect but also shows when and why a salesperson's brand-aligned physical appearance is most influential in shaping customers' affective responses toward the brand. The findings of our study have several theoretical implications.

First, Studies 1 and 2 show that customers feel more favorable brand affect when the salesperson's overall look is congruent with the firm's brand personality. This finding contributes to the service marketing literature by extending previous studies regarding branded service encounters (i.e., strategic association of a salesperson to brand perception; Sirianni et al. 2013), which mainly focused on the behavioral aspect of a salesperson. Our research has examined the impact of brand-congruent appearance of a salesperson on customers' affective responses toward the brand.

Second, our research investigates the underlying process of the aforementioned effect of salesperson-brand congruence on brand affect through the expectation-confirmation process, identifying the mediating role of positive affect. That is, the brand-congruent look of a salesperson increases positive affect among customers by confirming their prior expectations about what a salesperson for a certain brand should look like as a brand representative. This increased positive affect eventually increases brand affect.

Third, Study 2 shows an important boundary condition for the findings of Study 1 by identifying the moderating role of dispositional social anxiety: the positive impact of salesperson -brand congruence on brand affect is significant only among customers who have high social anxiety. This finding contributes to the social anxiety and impression management literature, suggesting that customers with high social anxiety feel less social discomfort around a salesperson whose look is congruent with the brand personality because they do not perceive the salesperson as a target of impression management but rather as a brand representative and an important source of brand information.

\subsection{Practical Implications}

Our findings not only contribute to the branded service encounters and aesthetic labor literature but also provide practical implications in terms that management of the physical appearance of a frontline employee is much easier to accomplish than strategical alignment of the salesperson behavior with brand personality. While the physical appearance of a salesperson can be easily modified and controlled to match the brand personality by simply changing the way (s) he dresses and encouraging him (her) to wear the brand-representing products, the brand-aligned behavior of a salesperson requires much more time and effort. It is usually more difficult to change one's attitude or behavior, which is an outcome of one's distinctive life experiences and nature.

Also, physical appearance of a salesperson 
would play a more important role in alluring customers to engage in shopping for certain brands, considering that visual stimuli often allow for customers to form immediate and instinctive first impression of the brand. In fact, only after customers find the first impression of the brand favorable enough to enter a store, a salesperson is given an opportunity to interact with customers and persuade them with his (her) brand-aligned behaviors and other marketing tactics.

Furthermore, the moderating effect of social anxiety found in Study 2 has important implications for marketing managers. Potential customers with high social anxiety, who would have otherwise avoided interacting with salespeople, can be encouraged to get inside the store and engage in shopping by simply aligning the salesperson look with brand personality.

\subsection{Limitations and Future Research}

Despite these contributions, we also recognize several limitations that provide room for future research. One of the limitations involves the scenario manipulation of the salesperson's physical appearance. Considering the nature of the salesperson look as a visual stimulus, a scenario may not be the most effective way to manipulate the overall physical appearance of a salesperson. Photographs or videos that are actually used in brand advertisements can be used to create a more vivid and realistic stimulus. Also, future research may extend the findings of our research by examining branded service encounters in service settings other than the apparel retail context. Furthermore, while this research focused on customers' affective responses toward the brand as the outcome of salesperson-brand congruence, it would be useful to explore the salesperson's role as an extrinsic cue that signals service quality and product performance. Although previous research examined the impact of many extrinsic cues (i.e., price, brand, and store display) on customers' perception of quality and value (Richardson, Dick and Jain 1994; Teas and Agarwal 2000), it has not examined the salesperson's physical appearance as one of the extrinsic cues.

〈Received February 27. 2018〉

〈Accepted August 9. 2018〉

\section{References}

Aaker, J. L. (1997). Dimensions of Brand Personality. Journal of Marketing Research, 34(8), 347-356.

Aggarwal, P. (2004). The Effects of Brand Relationship Norms on Consumer Attitudes and Behavior. Journal of Consumer Research, 31(1), 87-101.

Bagozzi, R. P. \& Dholakia, U. M. (2006). Antecedents and Purchase Consequences of Customer Participation in Small Group 
Brand Communities. International Journal of Research in Marketing, 23(1), 45-61.

Barlow, J. \& Stewart, P. (2004). Branded Customer Service: The New Competitive Edge. San Francisco: Berrett-Koehler Publishers.

Bearden, W. O., Malhotra, K. M., \& Uscátegui, H. K. (1998). Customer Contact and the Evaluation of Service Experiences: Propositions and Implications for the Design of Services. Psychology \& Marketing, 15(8), 793-809. Cacioppo, J. T., Glass, C. R., \& Merluzzi, T. V. (1979). Self-Statements and Self-Evaluations: A Cognitive-Response Analysis of Heterosocial Anxiety. Cognitive Therapy and Research, 3(3), 249-262.

Chaudhuri, A. \& Holbrook, M. B. (2001). The Chain of Effects from Brand Trust and Brand Affect to Brand Performance: The Role of Brand Loyalty. Journal of Marketing, 65(2), 81-93.

Cialdini, R. B. (1993). Influence: The Psychology of Persuasion. New York: Collins Inc.

Costrich, N., Feinstein, J., Kidder, L., Marecek, J., \& Pascale, L. (1975). When Stereotypes Hurt: Three Studies of Penalties for SexRole Reversals. Journal of Experimental Social Psychology, 11(6), 520-530.

Crawford, M. T., Sherman, S. J., \& Hamilton, D. L. (2002). Perceived Entitativity, Stereotype Formation, and the Interchangeability of Group Members. Journal of Personality and Social Psychology, 83(5), 1076-1094.
Fenigstein, A., Scheier, M. F., \& Buss, A. H. (1975). Public and Private Self-Consciousness: Assessment and Theory. Journal of Consulting and Clinical Psychology, 43(4), 522-527.

Fournier, S. (1998). Consumers and Their Brands: Developing Relationship Theory in Consumer Research. Journal of Consumer Research, 24(4), 343-373.

Goodman, J. K., Cryder, E. C., \& Cheema, A. (2013). Data Collection in a Flat World: The Strengths and Weaknesses of Mechanical Turk Samples. Journal of Behavioral Decision Making, 26(3), 213-224.

Hayes, A. F. (2013). Introduction to Mediation, Moderation, and Conditional Process Analysis: A Regression-Based Approach. New York: Guilford Press.

Huber, J. \& McCann, J. (1982). The Impact of Inferential Beliefs on Product Evaluations. Journal of Marketing Research, 19(3), 324-333.

Ind, N. (2003). Inside Out: How Employees Build Value. Journal of Brand Management, 10(6), 393-402.

Jackson, L. A. \& Cash, T. F. (1985). Components of Gender Stereotypes: Their Implications for Inferences on Stereotypic and Nonstereotypic Dimensions. Personality and Social Psychology Bulletin, 11(3), 326-344.

Keller, K. L. (1993). Conceptualizing, Measuring, and Managing Customer-Based Brand Equity. Journal of Marketing, 57(1), 1-22. Krishna, A. (2016). A Clearer Spotlight on 
Spotlight: Understanding, Conducting and Reporting. Journal of Consumer Psychology, 26(3), 315-324.

Kunda, Z. \& Kathryn, C. O. (1995). Maintaining Stereotypes in the Face of Disconfirmation: Constructing Grounds for Subtyping Deviants. Journal of Personality and Social Psychology, 68(4), 565-579.

Leary, M. R. (1983). Social Anxiousness: The Construct and Its Measurement. Journal of Personality Assessment, 47(1), 66-75. Mitchell, C. (2002). Selling the Brand Inside. Harvard Business Review. 80(1), 99-101. Oppenheimer, D. M., Meyvis, T., \& Davidenko, N. (2009). Instructional Manipulation Checks: Detecting Satisficing to Increase Statistical Power. Journal of Experimental Social Psychology, 45(4), 867-872.

Park, C. W., Jaworski, B. J., \& MacInnis, D. J. (1986). Strategic Brand Concept-Image Management. Journal of Marketing, 50 (10), 135-145.

Pounders, K. R., Babin, B. J., \& Close, A. G. (2015). All the Same to Me: Outcomes of Aesthetic Labor Performed by Frontline Service Providers. Journal of the Academy of Marketing Science, 43(6), 670-693.

Rafaeli, A., Dutton, J., Harquail, C. V., \& Mackie-Lewis, S. (1997). Navigating by Attire: The Use of Dress by Female Administrative Employees. Academy of Management Journal, 40(1), 9-45.

Rao, A. R. \& Monroe, K. B. (1988). The
Moderating Effect of Prior Knowledge on Cue Utilization in Product Evaluations. Journal of Consumer Research, 15(2), 253264.

Richardson, P. S., Dick, A. S., \& Jain, A. K. (1994). Extrinsic and Intrinsic Cue Effects on Perceptions of Store Brand Quality. Journal of Marketing, 58(4), 28-36.

Schlenker, B. R. \& Leary, M. R. (1982). Social Anxiety and Self-Presentation: A Conceptualization Model. Psychological Bulletin, 92(3), 641-669.

Sirianni, N. J, Bitner, M. J., Brown, S. W., \& Mandel, N. (2013). Branded Service Encounters: Strategically Aligning Employee Behavior with the Brand Positioning. Journal of Marketing, 77(6), 108-123.

Spiller, S. A., Fitzsimons, G. J., Lynch, Jr. J. G., \& McClelland, G. H. (2013). Spotlights, Floodlights, and the Magic Number Zero: Simple Effects Tests in Moderated Regression. Journal of Marketing Research, 50(2), 277-288.

Teas, R. K. \& Agarwal, S. (2000). The Effects of Extrinsic Product Cues on Consumers' Perceptions of Quality, Sacrifice, and Value. Journal of the Academy of Marketing Science, 28(2), 278-290.

Wan, L. C. \& Wyer, R. S. (2015). Consumer Reactions to Attractive Service Providers: Approach or Avoid?. Journal of Consumer Research, 42(8), 578-595.

Warhurst, C., Nickson, D., Witz, A., \& Cullen, 
A. M. (2000). Aesthetic Labour in Interactive Service Work: Some Case Study Evidence from the 'New' Glasgow. Service Industries Journal, 20(3), 1-18.

Weber, R. \& Crocker, J. (1983). Cognitive Processes in the Revision of Stereotypic Beliefs. Journal of Personality and Social Psychology, 45(5), 961-977.
Wentzel, D. (2009). The Effect of Employee Behavior on Brand Personality Impressions and Brand Attitudes. Journal of the Academy of Marketing Science, 37(3), 359-374.

Wenzel, A. \& Emerson, T. (2009). Mate Selection in Socially Anxious and Nonanxious Individuals. Journal of Social and Clinical Psychology, 28(3), 341-363. 